\title{
Impact of the Panama Canal expansion on Latin American and Caribbean ports: difference in difference (DID) method
}

\author{
Kahuina Miller ${ }^{*}$ (D) and Tetsuro Hyodo
}

\author{
* Correspondence: kahuinam@ \\ gmail.com \\ Department of Logistics and \\ Information Engineering, Tokyo \\ University of Marine Science and \\ Technology, 2-1-6, Etchujima \\ Koto-ku, Tokyo 135-8533, Japan
}

\begin{abstract}
The expanded Panama Canal opened on June 26, 2016. This expansion is the third set of locks that enabled the canal to double its capacity through the addition of new traffic lanes, which allowed neo-Panamax and some post-Panamax vessels to transit across the canal. The widening of the canal has increased maritime traffic within Latin America and the Caribbean (LAC). Major ports in the regions have made huge investments in port expansion and infrastructural development to accommodate neo-Panamax vessels. In this study, we investigated the impact of the Panama Canal expansion (PCE) on the Latin America and the Caribbean (LAC) ports by using the Difference in Difference (DID) method. This impact was evaluated for 100 major and regular ports within the three sub-regions of LAC, namely Caribbean, Central, and South America, before and after the treatment effect, that is, the PCE. The findings from the model revealed that the average container port throughput (TEUs) for the treated ports (DTrp) was more than that of the controlled ports (CONTp) with transshipment hub, Central America, and South America having 20\%, $12 \%$, and $34 \%$ growth, respectively, since the PCE (the treatment) except for the Caribbean ports (DTrp), which experienced losses of $8 \%$ within the LAC region from 2010 to 2019.

Keywords: Maritime traffic, Panama Canal, Difference in differences (DID), NeoPanamax vessels
\end{abstract}

\section{Introduction}

The Panama Canal (PC) is one of the two most strategic artificial waterways critical to global maritime trade, and the other is the Suez Canal. The Panama Canal (PC) is a narrow isthmus approximately $65 \mathrm{~km}$ between the Caribbean Sea and the Pacific Ocean. The canal was completed on August 15, 1914, becoming an essential route connecting vessels sailing from the West and East coasts of the United States and the LAC regions (Cho et al. 2019). Before the canal's existence, the Cape horn was the only trading route for ships connecting the East and West Coast of the Americas, and vessels sailing from Europe to the West coast had to sail around the Cape horn of South America (Gro 2016). The Panama Canal (PC) is the shortest operative route

(c) The Author(s). 2021 Open Access This article is licensed under a Creative Commons Attribution 4.0 International License, which permits use, sharing, adaptation, distribution and reproduction in any medium or format, as long as you give appropriate credit to the original author(s) and the source, provide a link to the Creative Commons licence, and indicate if changes were made. The images or other third party material in this article are included in the article's Creative Commons licence, unless indicated otherwise in a credit line to the material. If material is not included in the article's Creative Commons licence and your intended use is not permitted by statutory regulation or exceeds the permitted use, you will need to obtain permission directly from the copyright holder. To view a copy of this licence, visit http://creativecommons.org/licenses/by/4.0/. 
connecting maritime trade between the Atlantic and Pacific oceans. It is also the shortest passage for gas cargoes from the Gulf of Mexico to Northern Asia (Rodrigue 2015). For instance, for LNG carriers, the Gulf of Mexico's distance to Japan is approximately $17,064 \mathrm{~km}(9214 \mathrm{~nm})$ compared to $27,317 \mathrm{~km}(14,750 \mathrm{~nm})$ through the Suez Canal (Thomas 2015). The Panama Canal (PC) is essential to global trade, wherein an estimate of over $\$ 270$ billion worth of cargo crosses the canal each year; this serves over 140 maritime routes to over 80 countries (Panama Canal Authority 2019). The expansion was completed on June 26, 2016, allowing Neo-Panamax and some Post-Panamax vessels to transit; thus, increasing port competition, trade, cargo tonnage, and shipping activities within the regions for the US East and Gulf Coasts (Rodrigue 2020).

Mega-ships have increased the economy of scale in maritime transport, boosting regional ports' transshipment activities (ACS 2017). For example, In the Caribbean, global hub port terminals such as Kingston; Jamaica, Freeport; Bahamas, Caucedo; Dominican Republic, and Juan; Puerto Rico (US territory) seek to capitalize on the anticipated increase in transshipment activities. However, investments in deepening harbors and expanding capacity handling may not be sustainable or profitable due to increased competition among regional ports (Gooley 2018). The widening of the canal and the increase in container volume have provided promised growth for United States cargo and transportation among East and Gulf coast ports such as New York and New Jersey, Port of Houston, South Carolina Ports, Port of Miami, et cetera. However, to what extent has this expansion impacted container port throughput (TEUs) growth within the LAC region. It is essential to quantify the impact that PCE contributes to the LAC region to determine if ports benefit from this expansion (intervention). Major ports in the LAC region have made substantial investments towards improving port services and infrastructure. However, are these investments reaping success in container throughput growth (container handled at ports that include the port of origin, destination, and transshipment)? An impact evaluation of the PCE among LAC ports is vital for improving strategies to mitigate endogenous and exogenous factors that may contribute to unsatisfactory outcomes (Hawkins et al. 2015). These factors may include port development, international trade, economics, and policies that directly impact TEU growth (Notteboom et al. 2021).

This paper seeks to analyze the impact of the PCE among 100 ports within the Caribbean, Central, and South America sub-regions. One of the impact evaluation methods, Difference in Difference (DID), will determine the overall and sub-regional causal effects. This evaluation aims to use the DID as an alternative method for assessing a policy and interventions' causal effect in the maritime sector.

\section{Literature review}

\section{Panama Canal impact on the regions}

Undoubtedly, the expansion of the Panama Canal has impacted both North America and LAC regions. It has allowed the transit of mega-ships such as Neo and Post Panamax vessels to increase container throughput (TEUs) and Cargo tonnage at ports within the region. PCE has increased competition among important transshipment ports in Panama, Brazil, Jamaica, Mexico, the Bahamas, and Dominican Republic (Rodrigue and Ashar 2016). Most of these countries have made considerable 
investments in port expansion, dredging, and logistics centers to accommodate and attract mega-ships to their shores.

Using an impact evaluation method was necessary to assess the impact of the expansion within this region. Hawkins et al. (2015, pp. 26) define impact as a longer-term result generated by policy decisions, often through intervention, project, or programs. The PCE project has influenced the Americas' subprojects, including the LAC region, in dredging and port infrastructural improvements (Link 2015). Rodrigue and Ashar (2016), UNCTAD (2014), and Singh et al. (2015) stated that the advent of Mega-ships through the now expanded canal would influence greater transshipment yield and container traffic among transshipment ports. On the other hand, Marle (2016) alluded that the PCE has raised fears that the LAC container terminals were overcapacity due to port infrastructure and usage. Gooley (2018) also stated that the Port of Panama (ACP) indicated that some carriers shift from mega-ships due to high operating costs per container. He further stated that International Maritime Organization (IMO) mandated on January 1, 2020, that the use of low sulfur fuel could see more ships slow steaming to reduce fuel consumption by using the longer Suez route instead of shorter transits via Panama.

The expansion of the Panama Canal has impacted ports on the East and Gulf ports of the USA. According to Bhadury (2016) and Park et al. (2020), the PCE has increased cargo traffic flow from the West Coast to the East Coast, decreasing transportation costs and increasing transit time. This impact will enable more cargo traffic to transit the Panama Canal and increase transshipment activities within the Caribbean region. Nicholson and Boxill (2017) strongly believe that if most of the US East Coast ports become "ship ready" by improving port infrastructure such as longer quays, bigger cranes to accommodate 18 to 22 containers, more storage space for containers, deeper channel and berth, and higher bridges, then most Caribbean ports could see a reduction in transshipment activities. For example, ports such as Baltimore, Charleston, Miami, Philadelphia, and Virginia have official increases in container throughput (TEUs) due to ships transiting the expanded Panama Canal.

\section{Panama Canal impact on liner shipping and trading routes}

The World Shipping Council (WSC) (2019) defines Liner shipping as the service of transporting goods utilizing high-capacity, ocean-going ships that regular transit routes on fixed schedules. World Shipping Council (WSC) (2019) further stated there were 400 liner services in operation providing weekly sailing from the port of call. Several authors studied the impact of the PCE on liner shipping concerning routes section, intermodal options, container vessel sizing, economic growth, and trading routes. The PCE had substantial impacts on the structure of liner services in terms of capacity deployment. Rodrigue (2020) stated that the first notable impact was the rapid transition from Panamax ships towards Neo-Panamax ships for Deep-sea services between major ports.

Pham et al. (2018) studied the PCE and its effects on East and West Liner Shipping route choice. An empirical study was conducted for ocean-borne trade between New York and Hong Kong. They examined route selection decisions for the PCE post-era by combining qualitative and quantitative studies. Using a two-stage methodological 
framework to assess both the Panama and Suez Canals and the US intermodal system alternative route competitiveness. The findings indicated that transportation was an essential element for route selection, followed by the duration of transportation, dependability, and route characteristics. The Panama Canal was the preferred route over the Suez and US intermodal options.

Fan and Gu (2019) studied the PCE impact on container shipping route networks. They used a dual-target route distribution model to evaluate the PCE. The results revealed that during the PCE post-era, 15,000 TEU and 6500 TEU container vessels were mainly deployed through the expanded canal while 8500 TEU, 10500 TEU, and 12,500 TEU used the Suez Canal.

Wang (2017) studied the impact of the Panama Canal on global shipping. The research was based on empirical studies using annual reports and publications from the Panama Canal Authority (ACP). Findings revealed that the expansion had generated more revenue since the Neo-Panamax vessel deployment, which has resulted in further economic growth for Panama.

Liu et al. (2016) analyzed the potential impacts of the PCE on the advancing competitive, collaborative relations and the allocation of market dominance among the supply chain (SC) players on US container markets. Cooperative Game theory was used to assess this impact. The results revealed that Mega-ships transiting the canal would increase East Coast markets by $32 \%$ while negatively impacting West Coast markets by $22 \%$. Findings also revealed that the Ocean Carrier sub-coalition between West Coast SC companies would shift to the preferred sub-coalition between Ocean Carriers and East Coast SC companies after the PCE.

Carral et al. (2018) studied the impact of PCE on vessel size and seaborne transport. Statistical analysis was used to assess this effect on the type and size of ships transiting the canal. The findings revealed that growth in size and traffic for the container, LNG, and LPG vessels had significant growth since PCE.

Zupanovic et al. (2019) analyzed the impact of PCE on cost-saving in the shipping industry. The paper examined operational cost savings for three types of post-Panamax vessels; bulk, container, and tanker vessels on three different routes. The results revealed savings range from 33 to $76 \%$, equivalent to saving from US $\$ 227,562$ to US\$ 1,042,324. Hence the PCE will result in a significant saving for specific categories of ships.

Shibasaki et al. (2018) studied the anticipated impact of PCE and Northern Sea routes on LNG imports of Asian countries from macroeconomic and diversification perspectives from exporting countries. The finding revealed that the divergence of exporting countries for LNG imports was not affected by the change in Japan's import pattern, and some degree of impact was observed for these countries' national economies.

Achurra-Gonzalez et al. (2016) studied the use of different liner shipping network scenarios such as natural disasters or infrastructure development impacts on container trade routes. They used a cost-based network model for Southeast Asia to Europe liner shipping trade. The results suggested that interconnectivity was susceptible to disruptions.

Van Hassel et al. (2020) analyzed the PCE influence on perspective shifts of cargo flow from US and European ports. They used model design to calculate the container transportation cost using the Panama Canal. Studies were conducted before and after the PCE for shipments from the US to Europe. The study concluded that the expansion had impacted port selection mainly for the United States and, to a lesser extent Europe. 
Martinez et al. (2016) studied the PCE effect on the shipping routes of Asian imports into the United States. They investigated factors affecting routing decisions by using a Coast Choice Model. The simulation results showed that the PCE would generate significant time saving on shipments from Asia and was projected to shift significant traffic flow from West to East Coast ports, establishing vital policy repercussions for port operators on both coasts.

Reyes et al. (2019) studied the impact of PCE on Caribbean Ports. They examined how ports can adapt to the opportunities available from the expansion. Adaptive Port Planning (APP) framework was used to assess long-term planning for Caribbean ports. The study revealed that in the short-term Caribbean ports will experience decreases in transshipment container volume due to direct service deploying Neo-Panamax vessels calling to East Coast and Gulf of Mexico new ports.

All authors agree that the PCE has impacted the liner shipping and trading routes, resulting in comparative cost savings for some vessel classification. Undoubtedly, this shift in liner shipping routes will affect both Caribbean and US west coast ports.

\section{The advent of mega-ships to LAC (economy of scale)}

The Panama Canal is one of the main passages connecting the Pacific and Atlantic oceans, accounting for approximately $6 \%$ of global trade (FreightWaves 2020). According to Panama Canal Authority (2019), in 2018, United States, China, Japan, Mexico, and Colombia were the primary Canal users, with the United States account for $68.3 \%$ of the total cargo transiting the canal. This expansion has opened the doors to NeoPanamax and Post-Panamax vessels, impacting cargo throughput volumes for intraregional ports, US Gulf, and East coast ports.

Figure 1 shows that After the expansion in 2016, there was a surge in cargo tonnage through the expanded canal, while no significant changes were observed for the number of transits (Rodrigue 2020). Several authors supported the positive effects of megaships on international and regional ports.

Merk (2018) stated that doubling the maximum container ship size has reduced total vessel cost per transported container by roughly a third over the last decade. OECD (2015) supported his view, stating that containerization has contributed to decreased transportation costs. On the other hand, Lim (2011) studied the economies of scale in container shipping. The findings revealed that although huge container ships will

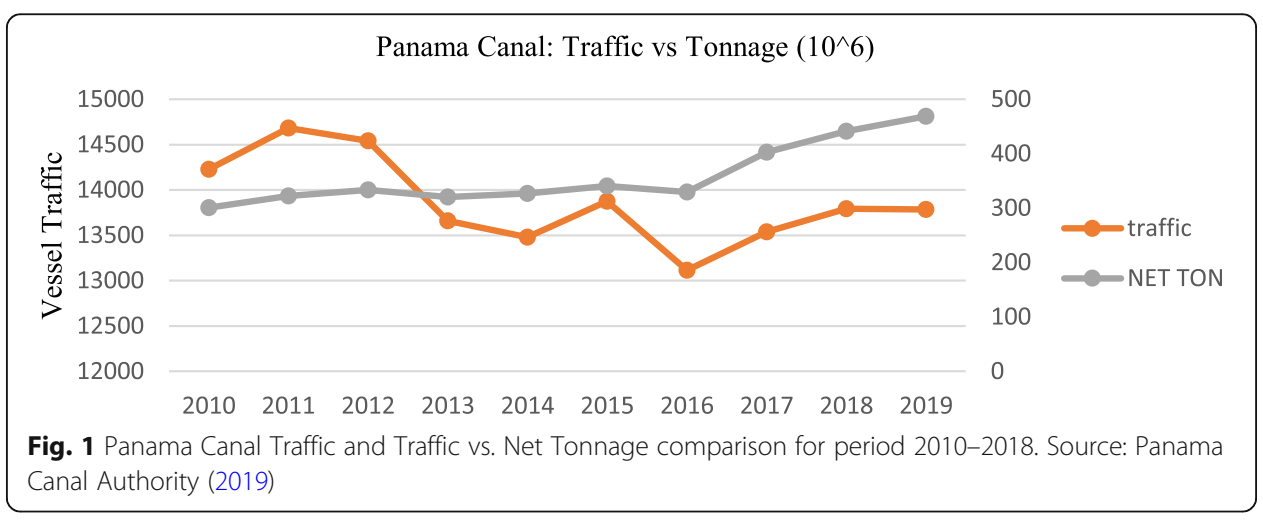


produce economies of scale and significantly reduce the slot cost in container trade to which ship assigned, the industry may never make an adequate return because of over demand. Therefore, the benefits of economies of scale will diminish over time. Kapoor (2016) studied the economics of scale for mega container vessels. The report revealed four (4) significant findings; (1) that the economies of scale diminish for vessel sizes beyond 18,000 TEUs; (2) that terminals will incur significant capital expenditure to handle larger vessels size and requires terminal yard to increase by third in order to avoid congestion; (3) terminal will have to increase productivity to compile with the increase in vessel size and (4) vessel upsizing risk the results of no significant cost benefit that will furthermore contribute to higher supply chain risk as volumes will be concentrated on fewer ships that will compile environmental issue of dredging deeper channels. Overview of the authors revealed that vessels were getting larger because of the theory of economy of scale. However, the effects of diminishing 'scale of economic' of megaships may not be necessarily beneficial for some regional ports.

The impact of the PCE on the US ports and LAC region has been studied by several authors such as Rodrigue and Ashar (2016), Singh et al. (2015), Bhadury (2016), and Park et al. (2020). They strongly agreed that PCE had impacted port infrastructure improvement within both regions. Pham et al. (2018), Rodrigue (2020), Fan and Gu (2019) studies agreed that PCE has influence liner shipping, trading routes, and cost savings for LAC and US ports on both east and west coasts. Several authors, such as Merk (2018), Lim (2011), Kapoor (2016), and Rodrigue (2020), strongly agreed that the advent of mega-ships had impacted container throughput and cargo tonnage. On the other hand, few authors address the causal effects of PCE on the LAC regional ports before and after the expansion to determine its overall impact. Several methodology applications such as port choice, route planning, adaptive port planning, and Cost-base analysis models were used to assess the effect of this expansion on global and US ports. However, limited authors use impact evaluation methods to determine the causal impact of the PCE as an intervention within the LAC. This research gap will be addressed using impact evaluation; Difference in Difference (DID), to assess the PCE implications for all three LAC sub-regions and transshipment ports.

\section{Method and data}

\section{Competition among ports on the US East Coast for cargo}

The PCE has influenced the development of ports within the US, especially on the East Coast, regarding traffic patterns, infrastructural upgrades, and intermodal connectivity (Kendrick 2020). The anticipated projection for improvement in the shipping industry among the East Coast and the Gulf of Mexico has increased container throughput growth (TEUs). This growth was because more container ships from Asia will directly access East Coast markets (Morley and Ashe 2019).

Table 1 shows the container throughput for five major ports on the East and Gulf coasts. In 2019, TEUs growth percentage, the port of New York and New Jersey (4\%), Port of Houston (11\%), Port of Miami (3\%), Port of Charleston (5\%), and the Port of Savannah (6\%). These improvements in East Coast and Gulf of Mexico ports attract more container traffic at the expense of ports within the Caribbean and some parts of the Americas (Morley and Ashe 2019). 
Table 1 Top 5 US East and Gulf of Mexico Ports, TEU annual Percentage Growth (\%)

\begin{tabular}{llllll}
\hline Year & Port of NY/NJ & Port of Houston & Port of Miami & Port of Charleston & Port of Savannah \\
\hline 2010 & $16 \%$ & $1 \%$ & $5 \%$ & $16 \%$ & $25 \%$ \\
2011 & $4 \%$ & $3 \%$ & $7 \%$ & $1 \%$ & $4 \%$ \\
2012 & $0 \%$ & $3 \%$ & $0 \%$ & $10 \%$ & $1 \%$ \\
2013 & $-1 \%$ & $1 \%$ & $-1 \%$ & $6 \%$ & $2 \%$ \\
2014 & $6 \%$ & $0 \%$ & $-3 \%$ & $12 \%$ & $10 \%$ \\
2915 & $-10 \%$ & $9 \%$ & $15 \%$ & $10 \%$ & $12 \%$ \\
2016 & $-2 \%$ & $2 \%$ & $2 \%$ & $1 \%$ & $-2 \%$ \\
2017 & $7 \%$ & $13 \%$ & $0 \%$ & $9 \%$ & $11 \%$ \\
2018 & $7 \%$ & $10 \%$ & $6 \%$ & $6 \%$ & $8 \%$ \\
2019 & $4 \%$ & $11 \%$ & $11 \%$ & $5 \%$ & $6 \%$ \\
\hline
\end{tabular}

Source: Own Elaboration

The top 5 major ports within the region have experienced small increases in TEUs except for the port of Balboa. The improvement of US East and Gulf ports has increased competition among East Coast for cargo, impacting transshipment volumes within the LAC region.

Table 2 shows the top five ports within the LAC region regarding the annual percentage growth in TEUs from 2010 to 2019. Among five other transshipment hubs, these ports represent approximately 84.1\% of cargo's total regional movement (CEPAL 2020). The TEU growth (\%) for port of Colon (1\%), Port of Santos (2\%), Manzanillo (0\%), Cartagena (2\%) and Balboa (15\%).

The comparison of container throughput (TEU) growth shown in Fig. 2, the percentage of US East and Gulf ports vs. top 5 LAC ports, shows that in 2019, the top 5 East coast ports recorded more percentage growth than LAC ports.

\section{The difference in difference (DID)}

An impact evaluation provides evidence about the impacts that have been produced or the impacts that are expected to be produced (Hawkins et al. 2015). The choice of methods and designs for evaluating policies, projects, and programs, can be difficult to

Table 2 Top 5 LAC ports percentage growth (\%) in container throughput

\begin{tabular}{llllll}
\hline Year & Colon, Panama & Santos, Brazil & Manzanillo, Mexico & Cartagena, Colombia & Balboa, Panama \\
\hline 2010 & $27 \%$ & $20 \%$ & $36 \%$ & $28 \%$ & $37 \%$ \\
2011 & $20 \%$ & $10 \%$ & $17 \%$ & $17 \%$ & $17 \%$ \\
2012 & $4 \%$ & $-1 \%$ & $13 \%$ & $19 \%$ & $2 \%$ \\
2013 & $-5 \%$ & $17 \%$ & $6 \%$ & $-10 \%$ & $-4 \%$ \\
2014 & $-2 \%$ & $3 \%$ & $11 \%$ & $13 \%$ & $9 \%$ \\
2015 & $9 \%$ & $2 \%$ & $8 \%$ & $8 \%$ & $-5 \%$ \\
2016 & $-9 \%$ & $-7 \%$ & $1 \%$ & $-4 \%$ & $-9 \%$ \\
2017 & $19 \%$ & $5 \%$ & $10 \%$ & $15 \%$ & $0 \%$ \\
2018 & $11 \%$ & $7 \%$ & $9 \%$ & $7 \%$ & $-16 \%$ \\
2019 & $1 \%$ & $2 \%$ & $0 \%$ & $2 \%$ & $15 \%$ \\
\hline
\end{tabular}

Source: Own Elaboration 


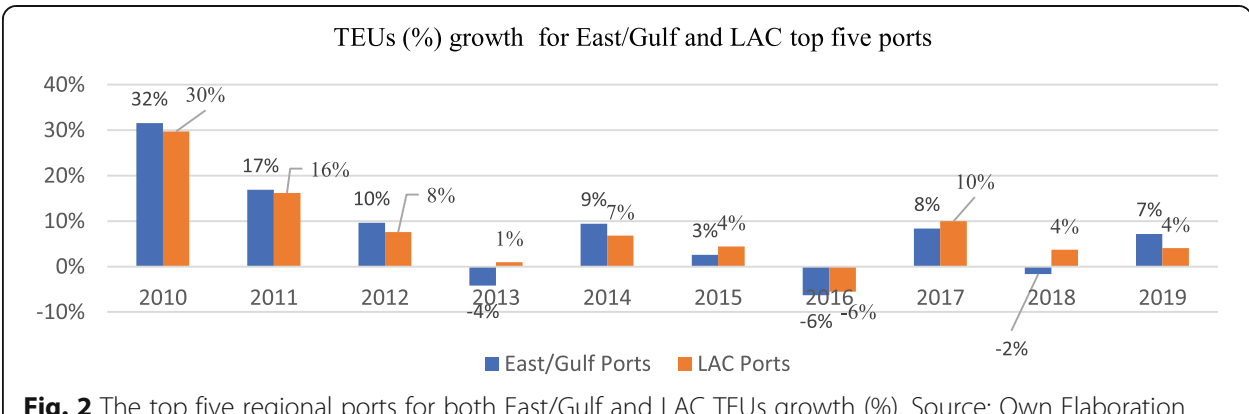

Fig. 2 The top five regional ports for both East/Gulf and LAC TEUs growth (\%). Source: Own Elaboration

be evaluated and may come with unique challenges (Hawkins et al. 2015). White and Sabarural (2014) stated that a quasi-experimental approach is an empirical intervention study used to estimate an intervention's causal impact or test causal hypotheses. The most frequently used quasi-experiment approach is Differences in Differences (DID), based on a combination of before - after and treatment - control group comparisons (Fredriksson and Oliveira 2019; World Bank 2021). Several authors used the Difference in Difference (DID) approach to assess government policies and programs' impact and their effectiveness.

Card and Krueger (1994) studied the impact of the increase in the minimum wage on employment for fast-food restaurants in New Jersey, the US, and Eastern Pennsylvania before and after the increase. The findings revealed that by using DID. There was no indication that an increase in the minimum wage reduced employment. Qiu and $\mathrm{He}$ (2017) researched the impact of the Green Traffic Policy on air quality in China. They concluded that the pilot program was effective in reducing the annual concentration of pollutants.

However, although the DID method is popular among various research fields, it is not without limitations. Bertrand et al. (2003) mention that the great appeal for DID estimation comes from its simplicity and potential to circumvent many of the endogeneity problems that arise when comparing heterogeneous groups. Wing et al. (2018) supported Bertrand et al. (2003) view, they stated that the Difference in Difference (DID) design was not an ideal alternative for randomized experiments, but it often signifies as a viable way to learn about causal relationships. They further concluded that multiple quasi-experimental techniques might be an essential support for the Difference in Difference (DID) approach.

\section{Parallel trend assumption (PTA)}

All the assumptions of the Ordinary Least Square Model apply equally to Difference in Difference (DID). Many assumptions, such as Parallel Trend Assumption (PTA), exchangeability, and Stable Unit Treatment Value Assumption (SUTVA), must hold to ensure the models' internal validity (Columbia Public Health 2020; Mckenzie 2021). Two of the most popular assumptions are Parallel Trend Assumption (PTA) and Stable Unit Treatment Value Assumption (SUTVA).

According to Lechner (2011), SUTVA indicates that there should be no spill-over influences between the treatment and control groups, as the treatment effect would then not be identified. The Parallel Trend Assumption (PTA) is the most critical of the 
above assumptions to ensure the DID Model's internal validity and may be difficult to execute because it requires that the difference between the treatment and control groups be constant over time (Lechner 2011). The assumption is fundamentally untestable because the treatment group is only observed as treated (Fredriksson and Oliveira 2019). "One can lend support to the assumption, however, using several periods of prereform data, showing that the treatment and control groups exhibit a similar pattern in pre-reform periods" (Fredriksson and Oliveira 2019, p.523).

These studies focused on using the DID approach for assessing treatment effects on policies and programs in the sector of education, finance, and the public sector economic, healthcare, sales, and marketing. This research will focus on using the DID model for the Maritime Industry to assess the PCE impact on TEUs growth among ports in Latin America and the Caribbean regions (LAC).

\section{Model}

Albouy (2015) evaluated an intervention, program, or treatment on an effect Y over an individual's population. Two groups were indexed by treatment status $\mathrm{T}=0,1$ where 0 denotes individuals who were not offered treatment, classified as the control group, and 1 indicates the group that received treatment, classified as the treatment group (Heckman et al. 1997). Two time periods were assumed on the observed individual, $\mathrm{t}=0,1$ where 0 indicates a time before the treatment; pre-treatment and 1indicates a time after the treatment; post-treatment (Athey and Imbens 2006). All observations were indexed by $i=1 \ldots N$ whereby, the individuals will have two observations each, pre-treatment and post-treatment denoted as follows: for average sample outcome for the treatment group, $Y_{0}^{-T}$ and $Y_{1}^{-T}$ and the average outcome for the control group, $Y_{0}^{-c}$ and $Y_{1}^{-c}$.

The outcome of $Y_{i}$ was modeled by Albouy (2004) and Abadie (2005) in the following equation.

$$
Y_{i}=\alpha+\beta T_{i}+\gamma t_{i}+\delta\left(T_{i} . t_{i}\right)+\varepsilon_{i}
$$

Where $\alpha=$ constant term

$\beta=$ treatment group-specific effect (accounting for average permanent differences between treatment and control)

$\gamma=$ time trend common to control and treatment groups

\section{Simple pre versus post estimator}

According to Albouy (2015), "a simple Pre versus Post Estimator Consider first an estimator based on comparing the average difference in the outcome $Y_{i}$ before and after the treatment for the treatment group."

$$
\hat{\delta}_{1}=\hat{Y}_{1}^{T}-\hat{Y}_{0}^{T}
$$

The expectation of the estimator is as follows.

$$
\begin{aligned}
& E\left[\tilde{\delta}_{1}\right]=E\left[\hat{Y}_{1}^{T}\right]-\left[\hat{Y}_{0}^{T}\right] \\
& =[\alpha+\beta+\gamma+\delta]-[\alpha+\beta]
\end{aligned}
$$




$$
=\gamma+\delta
$$

According to Albouy (2015), the estimator will be biased $\gamma \neq 0$, which is the constant average differences in outcomes $Y_{i}$ Post-treatment, between the treatment.

\section{Simple treatment versus control estimator}

Now, considering the estimator that will be established on evaluating the median outcome $Y_{i}$, post-treatment, between the treatment and control groups,

$$
\hat{\delta}_{1}=\hat{Y}_{1}^{T}-\hat{Y}_{1}^{C}
$$

The expectation of the estimator is as follows.

$$
\begin{aligned}
& E\left[\tilde{\delta}_{1}\right]=E\left[\hat{Y}_{1}^{T}\right]-E\left[\hat{Y}_{1}^{C}\right] \\
& =[\alpha+\beta+\gamma+\delta]-[\alpha+\gamma] \\
& =\beta+\delta
\end{aligned}
$$

According to Albouy (2015), the estimator is biased so long as $\beta \neq 0$, which is the constant average differences in outcomes $Y_{i}$, post-treatment, between the treatment.

The difference in difference (DID) estimator

DID estimator is defined as the difference in the treatment group's average outcome before subtracting the control group's average outcome before and after treatment (Albouy 2015; Abadie 2005).

$$
\hat{\delta}_{D D}=\hat{Y}_{1}^{T}-\hat{Y}_{0}^{T}-\left(\hat{Y}_{1}^{C}-\hat{Y}_{1}^{C}\right)
$$

According to Albouy (2015), the expectation of this estimator will become unbiased.

$$
\begin{aligned}
& \hat{\delta}_{D D}=E\left[\hat{Y}_{1}^{T}\right]-E\left[\hat{Y}_{0}^{T}\right]-\left(E\left[\hat{Y}_{1}^{C}\right]-E\left[\hat{Y}_{1}^{C}\right]\right) \\
& =\alpha+\beta+\gamma+\delta-(\alpha+\beta)-(\alpha+\gamma-\gamma) \\
& =(\gamma+\delta)-\gamma) \\
& =\hat{\delta}_{D D}
\end{aligned}
$$

\section{The difference in difference (DID) model for LAC ports}

The following equation below shows the DID model formulation for LAC's TEUs outcome.

$$
\begin{aligned}
\text { TEUs }= & \alpha+\beta \text { TreatmentPort }+\gamma \text { PostTreatment } \\
& +\delta(\text { TreatmentPort } \cdot \text { Posttreatment })+\varepsilon_{i}(\text { Outcome })
\end{aligned}
$$

TEUs: the average container throughput for Latin America and Caribbean ports from the period 2010 to 2019.

Treatment Port $\left(\mathrm{DTr}_{\mathrm{p}}\right)$ : Treatment dummy variable $\mathrm{T}$ when $\mathrm{T}=1$ represents container port throughput above 1 million TEUs. Treatment port $\left(\mathrm{DTr}_{\mathrm{p}}\right)$ includes transhipments that are both global and intra-regional ports. Treatment port $\left(\mathrm{DTr}_{\mathrm{p}}\right)$ invest in port development in hinterland expansion, dredging, and ship to shore (STS) gantry 
cranes (Neo Panamax compatibility) before the Panama Canal expansion in July 26, 2016. $\mathrm{T}=0$, represents container port throughput below 1 million TEUs. Control Ports (CONTp) include regular ports (non-transshipment ports) that cannot accommodate Neo-Panamax and Post-Panamax container vessels. Post-Treatment (Post ${ }_{t}$ ) is the time variable dummy that reflects periods; 'Before' intervention $\mathrm{T}=0$ and 'After' intervention $\mathrm{T}=1$.

Table 3 further explains the descriptive classification of ports within the LAC region that will be used to measure the impact of the Panama Canal expansion. The sample size of 100 ports was selected from 118 LAC ports from thirty-one (31) countries. These ports were selected based on throughput volume (TEUs) that were greater than 20,000 TEUs. Therefore, ports with less throughput volume were removed from the observation. Ports excluded from the sample were mostly Eastern Caribbean and some Central America.

\section{Data analysis software}

STATA and R packages were used to analyze the impact of the PCE on the top 100 ports within the LAC region using the DID method.

\section{Data sample}

The data sample comprises 100 ports within the LAC region divided into three (3) subregions, South America, Central America, and the Caribbean. The container throughput (TEUs) data from these regional ports were retrieved from the CEPAL and the World Bank. Port profiles and characteristics data were retrieved from the following websites: Logistics Capacity Assessment, Marine Traffic, Ports.com, and regional port websites. The LAC regional ports within the research are listed in sub-regional categories, South America, Central America, and the Caribbean, as shown in Table 4.

Table 4 shows the sample data of 100 ports within the LAC region that will give this research conclusive results of the PCE's impact on regional and sub-regional ports. Table 5 shows the profile and characteristics of the top 25 ports within the region detailing the infrastructure of each port; Area, Mobile Crane, S.T.S. gantry, Depth, and the number of berths that can be used as variables that influence container throughput volume (output) for each port (Sarriera et al. 2015; Logistics Capacity Assessments (LCAs) 2021; Marine Traffic 2021; World Port Source 2021).

Table 3 Classification of Treatment and Control Groups (100 Ports) within LAC

\begin{tabular}{|c|c|c|}
\hline Groups & Code & Description \\
\hline $\begin{array}{l}\text { Treatment Ports } \\
\text { (DTrp) }\end{array}$ & 1 & $\begin{array}{l}\text { Treatment ports include transshipment ports and ports with annual throughputs } \\
\text { of over a million TEUs. } 500,000 \leq \text { TEUs } \leq 5,000,000 \text {. }\end{array}$ \\
\hline $\begin{array}{l}\text { Control Ports } \\
\text { (CONTp) }\end{array}$ & 0 & $\begin{array}{l}\text { Control ports include regular ports (non-transshipment ports) within the regions } \\
\text { with annual TEUs below } 1 \text { million. } 20,000 \leq \text { TEUs } \leq 500,000 \text {. }\end{array}$ \\
\hline Time & Code & Description \\
\hline \multirow{2}{*}{$\begin{array}{l}\text { Post-Treatment } \\
\left.\text { Period (Post } t_{t}\right)\end{array}$} & 1 & The period after the PCE from 2016 to 2019. Condition: $2016 \leq$ After $\leq 2019$ \\
\hline & 0 & $\begin{array}{l}\text { Period before the PCE from } 2010 \text { to } 2016 \\
\text { Condition: } 2010 \leq \text { Before } \leq 2016^{a}\end{array}$ \\
\hline
\end{tabular}

a the completion date for the expansion was July 26, 2016. Source: Own Elaboration 
Table 4 LAC Ports and Rankings 2020

\begin{tabular}{|c|c|c|c|c|c|}
\hline Rank & Port (County, Region) & Rank & Port & Rank & Port \\
\hline 1 & Colon, Panama, CA & 36 & Lirquen, Chile, SA & 71 & Imbituba, Brazil, SA \\
\hline 2 & Santos, Brazil, SA & 37 & Salvador, Brazil, SA & 72 & Georgetown, Guyana, SA \\
\hline 3 & Manzanillo, Mexico, CA & 38 & Mariel, Cuba, C & 73 & Purto Chipas, Mexico, CA \\
\hline 4 & Cartegena, Colombia, SA & 39 & Caldera, Chile, SA & 74 & Mazataland, Mexico, CA \\
\hline 5 & Balboa, Panama, CA & 40 & Paita, Peru, SA & 75 & Natal, Brazil, SA \\
\hline 6 & Callao, Peru, & 41 & Iquique, Chile & 76 & Puerto Plata, DR. C \\
\hline 7 & Guayaquill, Ecuador, SA & 42 & Port of Spain, $\Pi, C$ & 77 & Rosano, Argentina, SA \\
\hline 8 & San Antonio, Chile, SA & 43 & Fort de France,Martinque, C & 78 & Tuxpan, Mexico, CA \\
\hline 9 & Kingston, Jamaica, C. & 44 & Itaguai, Brazil & 79 & Castries, St Lucia, C \\
\hline 10 & San Juan, Puerto Rico, C. & 45 & Acujutla, El Salvador, CA & 80 & Georgetown, Cayman, C \\
\hline 11 & Buenos Aires, Argentina & 46 & Vitoria, Brazil, SA & 81 & San Lorenzo, Honduras, CA \\
\hline 12 & Freeport, Bahamas & 47 & Arica, Chile, SA & 82 & Austral, Chile, SA \\
\hline 13 & Lazaro C. Mexico, CA & 48 & Jarry/Point-a-Pier, Guate. CA & 83 & Llo, Peru, SA \\
\hline 14 & Caucedo, Dominican R., C & 49 & Point Lisas, T\&T, C & 84 & Bahia Blanca, Argentina, SA \\
\hline 15 & Tapai, Brazil & 50 & Corinto, Nicargo, CA & 85 & San Antonio Est ARG, SA \\
\hline 16 & Limon Moin, Costa Rico, CA & 51 & Nassau, Bahamas, C & 86 & Guaymas, Mexico, CA \\
\hline 17 & Veracrus, Mexico, CA & 52 & Puerto Bolivar, Ecuador, SA & 87 & Belize City, Belize \\
\hline 18 & Bueraventura, Colombia, SA & 53 & Progreso, Mexico, CA & 88 & San Andres, Colombia, SA \\
\hline 19 & Valpraiso, Mexico, CA & 54 & Barranquilla, Colombia, SA & 89 & Esmeraldas, Ecuador, SA \\
\hline 20 & Altamira, Mexico, CA & 55 & Zarate, Argentina, SA & 90 & Deseado, Argentina, SA \\
\hline 21 & Parangua, Brazil,SA & 56 & Vila do Conde, Brazil, SA & 91 & Madryn, Argentina, SA \\
\hline 22 & Rio Grande, Brazil, SA & 57 & Santa Marta, Colombia, SA & 92 & CPCP, St Vincent, C \\
\hline 23 & Montevideo, Uruguay & 58 & Puerto Castilla, Hondura, CA & 93 & Coatzacoalcos, Mexico, CA \\
\hline 24 & San Francisco, Brazil & 59 & Nieuwe Haven, Surinam, SA & 94 & Matarani, Peru, SA \\
\hline 25 & Puerto Cortes, Honduras, CA & 60 & Philipsburg, St. Maarten, C & 95 & Matarani-TISUR, Peru, SA \\
\hline 26 & Coronel, Chile & 61 & Coronel, Chile, SA & 96 & Big Creek, Belize, CA \\
\hline 27 & Santos Tomas, Guatemala, CA & 62 & La Guaira, Venezuela, SA & 97 & Manzanillo, DR, C. \\
\hline 28 & Haina, Dominica R. C. & 63 & Antofagasta, Chile, SA & 98 & Porto Velbo, Brazil, SA \\
\hline 29 & $\begin{array}{l}\text { Peurto Quetzai, Guatemala, } \\
\text { CA }\end{array}$ & 64 & Willemstad, Curacao, C & 99 & $\begin{array}{l}\text { General San Martin, Peru, } \\
\text { SA }\end{array}$ \\
\hline 30 & Swape Brazil, SA & 65 & Almirante, Panama, CA & 100 & Pisco, Peru \\
\hline 31 & $\begin{array}{l}\text { Puerto, Baitrios, Guatemala, } \\
\text { CA }\end{array}$ & 66 & Turbo, Colombia & & \\
\hline 32 & Pecem, Brazil & 67 & Oranjestad, Aruba & & \\
\hline 33 & Rio de Janerio, Brazil, SA & 68 & Santos Domingo, & & \\
\hline 34 & Talcahuano, Chile, SA & 69 & $\begin{array}{l}\text { Puerto Chiapas, Venezuela, } \\
\text { SA }\end{array}$ & & \\
\hline 35 & Ensenada, Mexico, CA & 70 & Degrad des Cannes, FG, SA & & \\
\hline
\end{tabular}

100 LAC ports listed, SA South America, CA Central America and C Caribbean regions Source: Own elaboration; Referred to CEPAL (2020)

\section{Quality of port infrastructure in the LAC region}

Quality of Port Infrastructure (QPI) evaluates business executives' view of a country's port facilities (World Economic Forum 2018). Improving port infrastructure quality contributes to higher logistics performance, seaborne trade, and higher economic 
Table 5 Characteristics of 25 LAC Ports

\begin{tabular}{|c|c|c|c|c|c|c|c|c|}
\hline Rank & Port & $\begin{array}{l}\text { Growth (\%) } \\
2010-2019\end{array}$ & $\begin{array}{l}\text { Ave TEUs } \\
(2010-2019)\end{array}$ & Area $\left(\mathrm{m}^{2}\right)$ & $\begin{array}{l}\text { Mobile } \\
\text { Crane with } \\
\text { Capacity }>4 \mathrm{t} \\
\text { (Units) }\end{array}$ & $\begin{array}{l}\text { STS Gantry } \\
\text { Cranes (Units) }\end{array}$ & $\operatorname{Depth}(m)$ & Berth \\
\hline 1 & Colon, Panama, CA & $56 \%$ & $3,577,481$ & 384,000 & 33 & 8 & 16.5 & 4 \\
\hline 2 & Santos, Brazil, SA & $44 \%$ & $3,404,192$ & 597,000 & 46 & 13 & 16 & 6.5 \\
\hline 3 & Manzanillo, Mexico, CA & $103 \%$ & $2,383,731$ & 437,000 & 8 & 9 & 16.5 & 13 \\
\hline 4 & Cartegena, Colombia, SA & $86 \%$ & $2,309,143$ & 225,000 & 2 & 28 & 21 & 8 \\
\hline 5 & Balboa, Panama, CA & $5 \%$ & $3,064,109$ & 300,000 & 8 & 17 & 16.5 & 13 \\
\hline 6 & Callao, Peru, & $72 \%$ & $1,948,871$ & 441,080 & 6 & 3 & 16 & 4 \\
\hline 7 & Guayaquill, Ecuador, SA & $73 \%$ & $1,651,670$ & 228,273 & 3 & 6 & 10.5 & 4 \\
\hline 8 & San Antonio, Chile, SA & $96 \%$ & $1,228,410$ & 495,000 & 6 & 13 & 15 & 9 \\
\hline 9 & Kingston, Jamaica, C. & $-13 \%$ & $1,710,747$ & $1,037,671$ & 3 & 19 & 15.5 & 11 \\
\hline 10 & San Juan, Puerto Rico, C. & $-1 \%$ & $1,361,987$ & 287,273 & 0 & 6 & 17 & 46 \\
\hline 11 & Buenos Aires, Argentina & $-14 \%$ & $1,598,995$ & $2,200,000$ & 10 & 13 & 10.7 & 5 \\
\hline 12 & Freeport, Bahamas & $24 \%$ & $1,226,886$ & 320,125 & 0 & 13 & 16 & 3 \\
\hline 13 & Lazaro C. Mexico, CA & $41 \%$ & $1,099,694$ & $1,850,000$ & 3 & 2 & 14 & 11 \\
\hline 14 & Caucedo, Dominican R., C & $-34 \%$ & $1,048,944$ & 800,000 & 2 & 6 & 15.2 & 15 \\
\hline 15 & Itapai, Brazil & $212 \%$ & 579,320 & 180,000 & 3 & 2 & 14 & 11 \\
\hline 16 & Limon Moin, Costa Rico, CA & $-56 \%$ & $1,090,248$ & 677,276 & 0 & 6 & 10.2 & 6 \\
\hline 17 & Veracrus, Mexico, CA & $33 \%$ & 924,736 & 402,909 & 1 & 5 & 14 & 3 \\
\hline 18 & Bueraventura, Colombia, SA & $0 \%$ & 927,158 & 68,500 & 3 & 8 & 15 & 14 \\
\hline 19 & Valpraiso, Mexico, CA & $-25 \%$ & 937,775 & 280,710 & 5 & 3 & 14 & 3 \\
\hline 20 & Altamira, Mexico, CA & $80 \%$ & 664,444 & 396,570 & 1 & 4 & 12 & 3 \\
\hline 21 & Parangua, Brazil,SA & $-11 \%$ & 735,064 & $4,129,000$ & 10 & 6 & 12.5 & 24 \\
\hline 22 & Rio Grande, Brazil, SA & $-16 \%$ & 691,709 & 536,023 & 8 & 3 & 16.5 & 2 \\
\hline 23 & Montevideo, Uruguay & $-4 \%$ & 807,434 & 12,000 & 7 & 8 & 14 & 11 \\
\hline 24 & San Francisco, Brazil & $493 \%$ & 315,620 & 247,947 & 17 & 6 & 16 & 13 \\
\hline 25 & Puerto Cortes, Honduras, CA & $-79 \%$ & 603,491 & 75,000 & 5 & 1 & 12.5 & 3 \\
\hline
\end{tabular}

Source: Own Elaboration

growth (Munim et al. 2018). Quality of port infrastructure, WEF (1 = extremely underdeveloped to 7 = well developed and efficient by international standards).

As shown in Fig. 3, the Quality of Port infrastructure in the LAC region has improved from 3.6 in 2007 to 3.96 in 2017. The highest score was recorded at 4.1 in 2010, then gradually declined through 2011 to 2015, then rebounded in 2016 to 3.96, which was the year that PCE was completed.

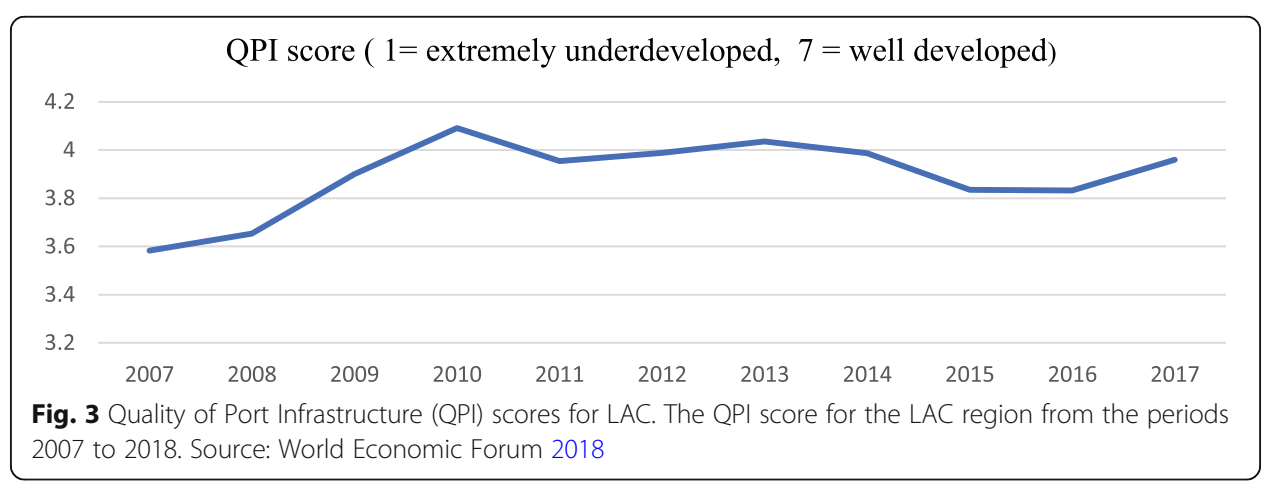




\section{Foreign direct investment (FDI)}

FDI is a key component in international economic amalgamation (OECD 2020). It is also a major investment funding source; therefore, developing countries offer incentives to encourage FDI (United Nations 2005). FDI has a positive effect on trade because companies expand their production operations for larger capital and borrow from international markets, thus benefiting from economies of scale, leading to an increase in trade for the host country (OECD 2020). FDI investment within the LAC region has increased since the inception of the expansion. For example, Panama's FDI growth has increased since the canal expansion (Lloyd 2017). Figure 4 shows the FDI (US\$) investment in LAC for the period 2010 to 2019 that 2013 was the highest recorded FDI, 3.812 Billion declined to 2.589 Billion in 2019. During the period 2017 to 2019, there was a gradual increase from 2.226 Billion (US\$) to 2.589 Billion (US\$), representing a $16 \%$ FDI growth in the region.

\section{Trade freedom (TRFR)}

TRFR is a composite measure of the absence of tariff and non-tariff barriers that affect the trade of goods and services. Trade freedom (TRFR) is based on the inputs: Tradeweight, average, and Non-tariff barriers (Index of Economic Freedom (IEF). 2020). The growth in trade freedom was declined from 74.8 in 2007 to 74.6 in 2014, then rebound to 74.7 in 2018, as shown in Fig. 5. It is showing that there were improvements in Trade Freedom (TRFR) within the region.

\section{Port liner shipping connectivity index (PLSCI) in LAC and Transhipment ports}

PLSCI assesses how well a country links to the global shipping networks (UNCTAD 2021). The LSCI is measured by five components of the maritime transport sector: number of ships, container-carrying capacity, maximum vessel size, number of services, and companies that deploy container ships in a country's ports (World Economic Forum 2018). Port infrastructure and PLSCI impacts freight rates in the LAC region (Wilmsmeier et al. 2006). The port liner connectivity is an important factor determining trade activity in the maritime industry for regional ports within LAC and US East and Gulf coast. The PCE has largely impacted LSCI. The growth of the LSCI is shown in Fig. 6 that reveals the average Liner shipping Connective Index (LSCI) for ports within the LAC region.

The average Port Liner Shipping Index (PLSCI) for the three (3) regions showed consistent growth in South America, Central America, and the Caribbean. As shown in Fig. 6, for South America (SA), the PLSCI score increases from 8.50 to 12.40, Central

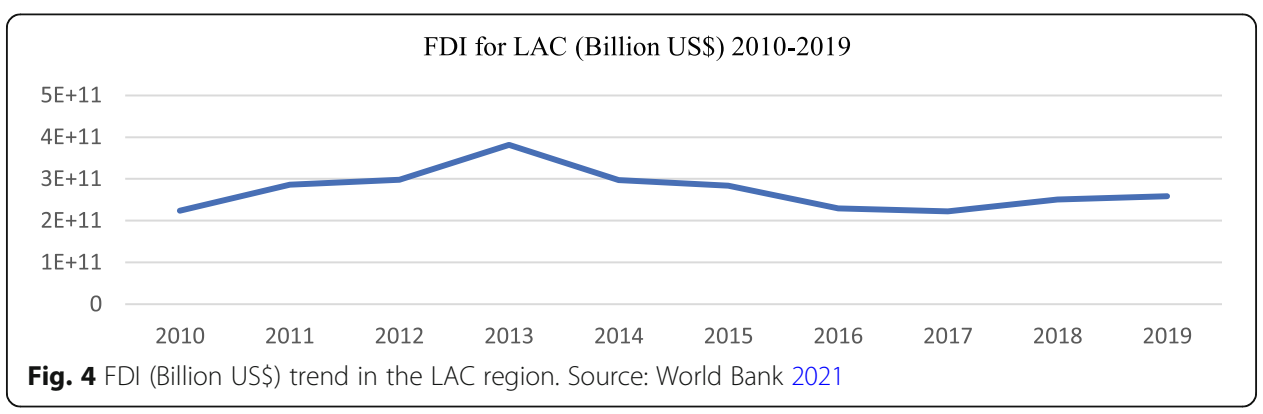




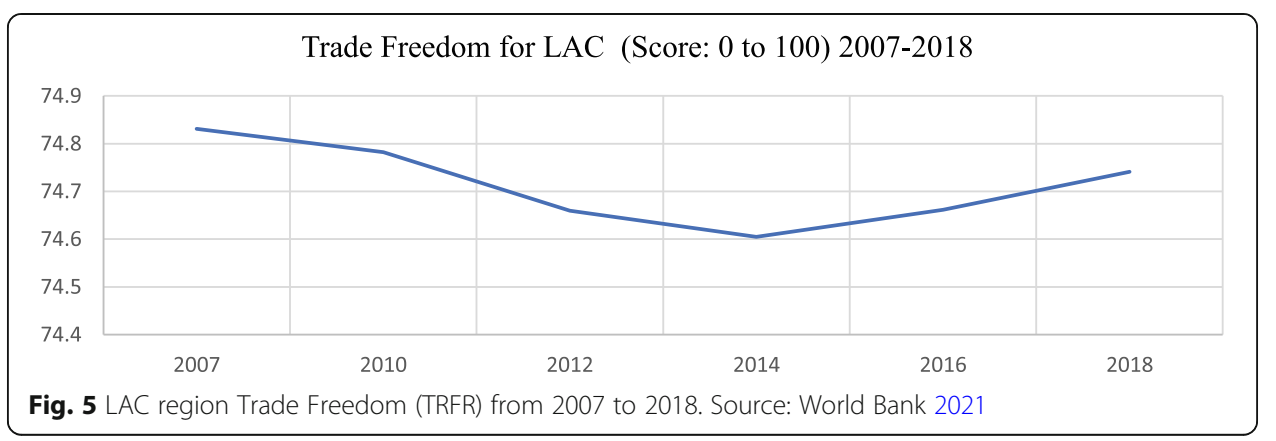

America (CA) score increases from 8.63 to 13.82, and the Caribbean score from 8.63 to 12.41. In 2019, the top three transshipment ports within the region located in Central America; Colon; Panama (33.2), Balboa; Panama (35.2), and Manzanillo; Mexico (37.8). Regional transshipment within the LAC such as Colon; Panama; Balboa; Panama; Cartagena; Colombia, Santos; South America, Kingston; Jamaica, Freeport; Bahamas, Buenaventura; Colombia, Caucedo; Dominican Republic, San Juan; Puerto Rico and San Antonio; Chile; PLCI scores were way above the average regional PLSCI scores.

\section{Results}

The results on the impact of the Panama Canal expansion (PCE) on LAC regional ports were conducted using the traditional Difference in Difference (DID) equation - i.e., exactly the specification described.

$$
\begin{aligned}
\text { TEUs }= & \alpha+\beta \text { TreatmentPort }+\gamma \text { PostTreatment } \\
& +\delta(\text { TreatmentPort } \cdot \text { Posttreatment })+\varepsilon_{\mathrm{i}}
\end{aligned}
$$

Where intercept $(\alpha)$, TreatmentPort $(\beta)$, PostTreatment $(\gamma)$, and Diff-in-Diff $(\delta)$ were all statistically significant at $1 \%, 5 \%$, and $10 \%$ levels as shown in Table 6 . The regression results for transshipment, Caribbean, Central America, and South America ports, $r$ values were $0.41,0.87,0.83$, and 0.31 . Table 7 , statistical description of three (3) subregional and transshipment hubs of 100 ports from the period 2010 to 2019; the coefficient $\beta$ for the treatment (DTrp) and Control (CONTp) ports, were all statistical significance at $1 \%$ level.

For transshipment hub ports, the estimated coefficient $\delta=0.077$ (statistically significant at the $10 \%$ level) and indicates that the average container port throughput (TEU)

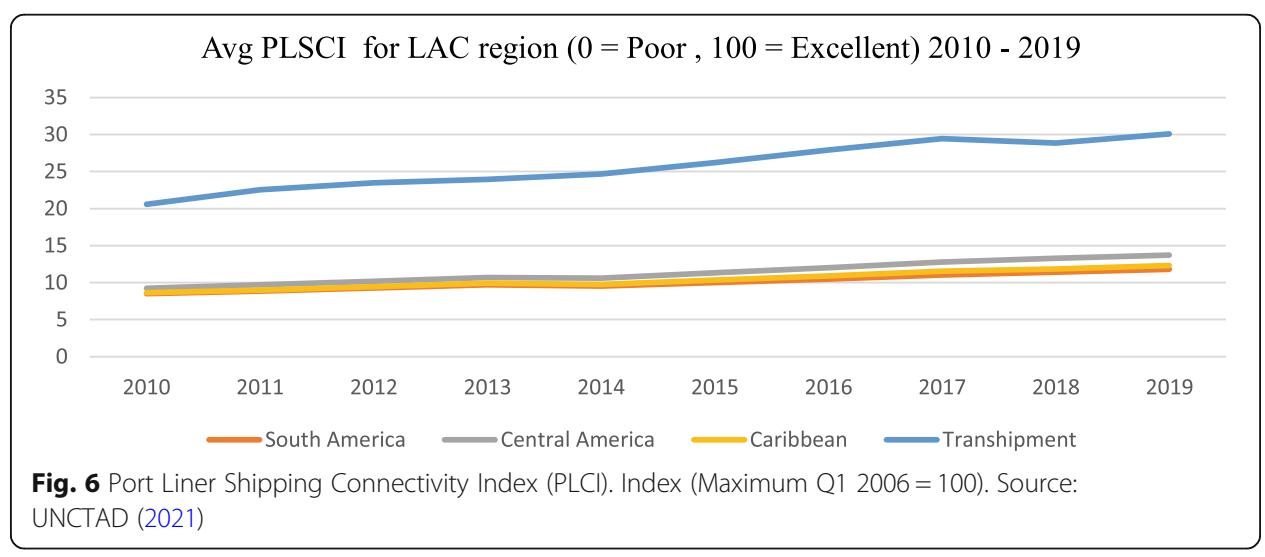


Table 6 Statistical Descriptive

\begin{tabular}{|c|c|c|c|c|c|}
\hline Variables & Obs & Mean & Std Dev & Min & Max \\
\hline \multirow[t]{3}{*}{ Transshipment Ports } & 870 & $527,308.2$ & $765,959.2$ & 2 & $4,379,477$ \\
\hline & Obs & & & Obs & \\
\hline & Before & & & After & \\
\hline Control (CONTp) & 390 & & & 260 & \\
\hline Treated (DTrp) & 132 & & & 88 & \\
\hline \multirow[t]{2}{*}{ Central America Ports } & 220 & $716,259.2$ & $1,003,011$ & 2 & $4,379,477$ \\
\hline & Before & & & After & \\
\hline Control (CONTp) & 390 & & & 260 & \\
\hline Treated (DTrp) & 132 & & & 88 & \\
\hline \multirow[t]{2}{*}{ Caribbean Ports } & 210 & $359,611.8$ & $502,276.6$ & 6214 & $1,891,770$ \\
\hline & Before & & & After & \\
\hline Control (CONTp) & 102 & & & 65 & \\
\hline Treated (DTrp) & 24 & & & 19 & \\
\hline \multirow[t]{2}{*}{ South America Ports } & 280 & $758,567.4$ & 792,303 & 59,583 & $3,904,566$ \\
\hline & Before & & & After & \\
\hline Control (CONTp) & 78 & & & 52 & \\
\hline Treated (DTrp) & 90 & & & 60 & \\
\hline
\end{tabular}

Source: Own Elaboration

of the DTrp increased by $20 \%(170,000$ TEUs) more than that of non-transshipment ports within the LAC region since the PCE. For the Caribbean region, the estimated coefficient $\delta=0.026$ (statistically significant at the 5\% level) and indicates that the average container throughput (TEU) for Treatment Ports (DTrp) decreased by $8 \%(140,000$ TEUs) less than control ports (CONTp). For the Central American region, the estimated coefficient $\delta=0.087$ (statistically significant at the $10 \%$ level) and an average

Table 7 Differences in Differences (DID) Regressions (2010 to 2019)

\begin{tabular}{|c|c|c|c|c|c|c|c|c|}
\hline \multirow[t]{2}{*}{ Variable } & \multicolumn{2}{|c|}{ Transshipment } & \multicolumn{2}{|c|}{ Caribbean C } & \multicolumn{2}{|c|}{ Central America (CA) } & \multicolumn{2}{|c|}{ South America (SA) } \\
\hline & Before & After & Before & After & Before & After & Before & After \\
\hline Control & 23,000 & 270,000 & 130,000 & 120,000 & 320,000 & 410,000 & 270,000 & 260,000 \\
\hline Treated & $1,300,000$ & $1,500,000$ & $1,300,000$ & $1,200,000$ & $2,900,000$ & $3,200,000$ & $1,100,000$ & 130,000 \\
\hline Diff (T-C) & $1,000,000$ & $1,200,000$ & $1,200,000$ & $1,100,000$ & $2,500,000$ & $2,800,000$ & 820,000 & $1,100,000$ \\
\hline S.Err. & 60,000 & 73,000 & 41,000 & 48,000 & 100,000 & 130,000 & 99,000 & 120,000 \\
\hline$t$ & 17.59 & 16.64 & 29.41 & 22.6 & 24.4 & 22.15 & 9.07 & 8.1 \\
\hline$p$-value & 0.001 & 0.001 & 0.001 & 0.001 & 0.001 & 0.001 & 0.001 & 0.001 \\
\hline Diff-in Diff (DID) & 170,000 & & $-140,000$ & & 280,000 & & 260,000 & \\
\hline$t$ & 1.77 & & 2.25 & & 1.72 & & 1.81 & \\
\hline$p$-value & $0.077^{*}$ & & $0.026^{* *}$ & & $0.087^{*}$ & & $0.095^{*}$ & \\
\hline S.Err. & 94,000 & & 63,000 & & 160,000 & & 260,000 & \\
\hline $\mathbf{R}$ & 0.41 & & 0.87 & & 0.83 & & 0.35 & \\
\hline
\end{tabular}

Note: the DID regression models for the dependent variable $Y$ (TEUs) is average container port throughput for the four (4) variables transshipment, Caribbean, Central, and South America. The Post-treatment period (After PCE) is equal to 1, 2016, 2017, 2018, 2019. Pre-Treatment period (Before PCE) is equal to 0 in 2010, 2011, 2012, 2013, 2014, 2015. The treated port and Controlled port results were used to determine the Diff (T-C) for each "Before and After" period for transshipment and the three (3) regional ports. The symbols * ${ }^{* *}$, and ${ }^{* *}$ indicate statistical significance at the $10 \%, 5 \%$, and $1 \%$ levels. Source: Own Elaboration 
container throughput (TEU) increase of 12\% (280,000 TEUs) than control ports (CONTp) since the PCE. For ports in the South American region, $\delta=0.095$ (statistically significant at the $10 \%$ level) and indicates $34.4 \%$ (260,000 TEUs) than control ports (CONTp) since the PCE.

\section{Parallel trend assumption test}

The Parallel Trend Assumption (PTA) was used to test the model's validity to ensure no biased estimation of causal effects (Fredriksson and Oliveira 2019). A validity check compares changes to the treatment and comparison group's changes before and after the program (Columbia Public Health 2020; Mckenzie 2021). Table 5 was used to classify the LAC ports into treatment (DTrp) and control (CONTp) groups from 2010 to 2019. Pretreatment period "Before" and "After" the PCE. Fig. 7 shows that in 2016, there were increases in container port throughput (TEUs) from 2017 to 2019 for the total summation of Treatment Ports $\left(\mathrm{DTr}_{\mathrm{p}}\right)$, while for the Control Ports $\left(\mathrm{CONT}_{\mathrm{p}}\right)$ constant trend was seen during those periods. Therefore, the parallel trend assumption holds for the Treated Ports (DTrp) and Control Ports $\left(\mathrm{CONT}_{\mathrm{p}}\right)$ because the Container throughput moves in tandem with each other until 2016, rapid growth container throughput (TEUs) was observed from that period to 2019 for the treated ports (DTrp).

\section{Discussion}

The DID Model results revealed that PCE (Intervention) positively impacted container port throughput (TEUs) within the LAC region. All estimated coefficients $\delta$ in the model were statistically significant at $1 \%, 5 \%$, and $10 \%$. The findings from the model revealed that the average container port throughput for Treated ports (DTrp) was more than that of Controlled ports (CONTp) for Transhipment hub, Central America, and South America having 20\%, 12\%, and 34\% growth since the canal expansion, except for the Caribbean ports (DTrp) that experienced losses of $8 \%$. These DID results were expected and supported by several authors and data resources such as Rodrigue and

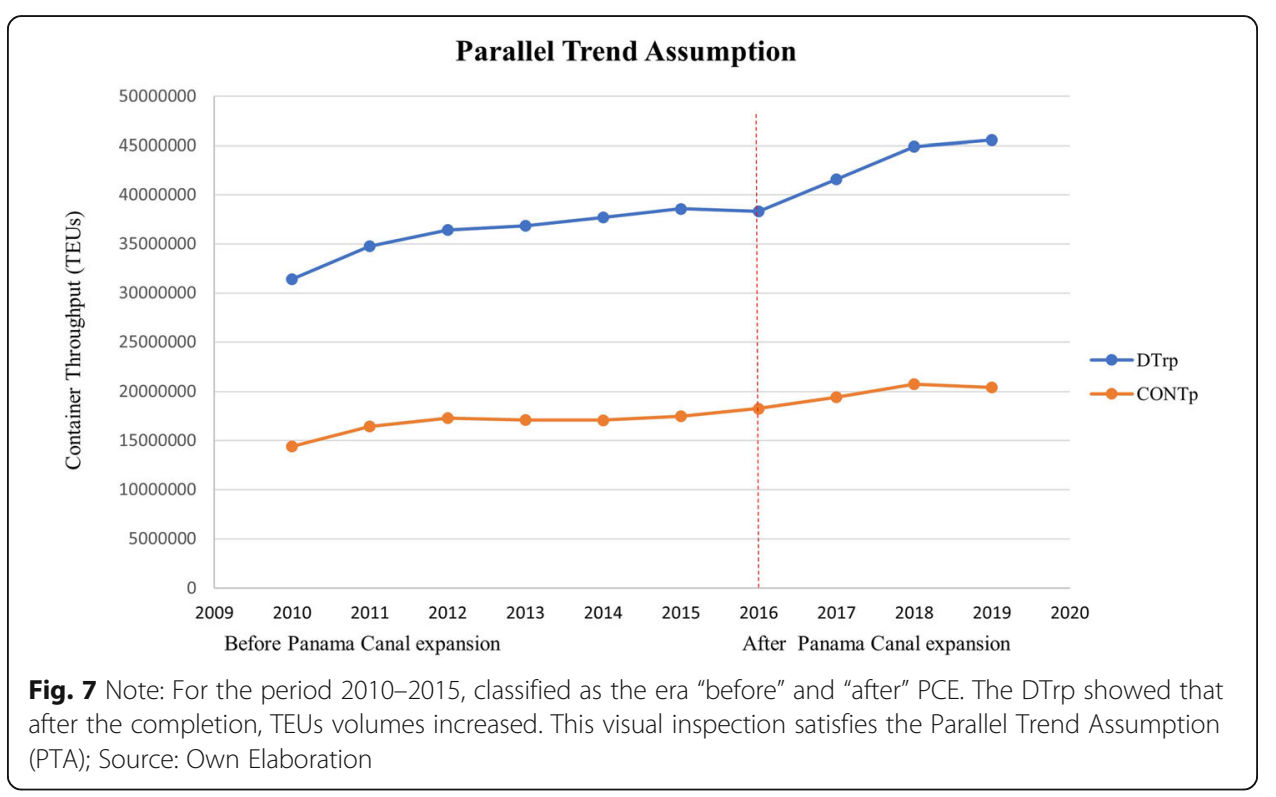


Ashar (2016), CEPAL (2020), World Bank (2021), UNCTAD (2014), Martinez et al. (2016), and Singh et al. (2015). For the positive impact of PCE (Intervention), Martinez et al. 2016, studies revealed that the PCE would generate significant transit time saving and shifting container traffic from West Coast to East Coast ports. Rodrigue and Ashar (2016) forecast increases in both transshipment activity and container throughput through the PCE. However, the Caribbean Treatment (DTrp) ports have experienced decreases in container port throughput based on the DID model's findings. This decline may be largely influenced by port infrastructural development and improvement of the US East and Gulf coast, increasing competition among US ports and regional ports (Van Hassel et al. 2020; Martinez et al. 2016). Ports that lack or delayed port modernization investments will experience losses in container throughput (TEUs) and changes in liner shipping routes (Talley 2006; Sarriera et al. 2015; Kendrick 2020). The DID results revealed that major Caribbean ports (DTrp) such as Kingston, Freeport, San Juan, and Caucedo had experienced losses in container throughput (TEUs) since the PCE. Reyes et al. (2019) and Park et al. (2020) supported this finding; Reyes et al. (2019) revealed that the short-term impact of Caribbean ports would decrease transshipment volume because port modernization investment among US ports will impact liner shipping routes.

The Canal expansion has reshaped US and LAC ports' economic and environmental geography beyond this research scope. However, other factors were considered, such as Quality of Port Infrastructure (QPI), Foreign Direct Investment (FDI), and Trade Freedom (TRFR) (Bhadury 2016; Prozzi and Overmyer 2018; Ashley and Dettoni 2016; United Nations 2005; Carral et al. 2018). These data were not included in the model but were considered supporting graphs to justify the expansion's pre- and post-era impact. Fig. 3 shows that the overall QPI scores have improved from 3.6 to 3.96. Fig. 4 shows FDI rebounded in 2017 from US\$2.22 Billion to US\$2.59 Billion in 2019. Fig. 5 reveals that TRFR improved from 74.6 in 2014 to 74.74 in 2018; simultaneously, it may be said that these variables may have influenced container port throughput (TEUs) growth. However, The PCE had impacted liner shipping routes, cargo tonnage growth, and port investment within LAC and US East and Gulf ports that resulted in water channel investments and improvement of policies to foster economic growth in anticipation of the PCE (Prozzi and Overmyer 2018; Bhadury 2016; Carral et al. 2018; Sarriera et al. 2015; Kendrick 2020; Rodrigue 2020).

The dynamics of trade globalization, development of transport technology, application of cargo-handling technology, and cargo unitisation are keen attributes that will determine regional ports' competitiveness (ICS 2020; Park et al. 2020; Nicholson and Boxill 2017). The Caribbean region (DTrp) ports' finding was unexpected because of the Transshipment history and strategic location of these ports being a part of the "Transshipment triangle" of the LAC region (Notteboom et al. 2021). These results also revealed that Mega-ships' introduction to the Caribbean region does not necessarily benefit transshipment ports due to the following: the inability to accommodate NeoPanamax, lack of proactiveness to global changes, poor port infrastructure, and competition from regional ports, especially the US and Gulf Coast port (Merk 2018; Kapoor 2016; Bhadury 2016; Park et al. 2020).

The twenty-first century shows that radical changes in the maritime trade will impact port operations' dynamics and their capability to compete for container traffic. Impact 
evaluation such as DID enables ports to assess an intervention's impact and efficiently make adjustments in trade policy reforms, port infrastructure, and most importantly, prepare them to be more resilient towards sustainable developments for the present and future dynamism in global trade.

\section{Limitations}

The sample size was taken from ECLAC and World Bank from 31 countries and 118 ports and port zones from 2010 to 2019 . The nine (9) timestamps may not fully justify the Parallel trend Assumption (PTA) of the DID model. However, the container throughput (TEUs) of 100 LAC ports gives a clearer perspective on the PCE's causal effect. Some regional ports, mostly Caribbean ports, were excluded from the model because of limited and missing data. Each of the 100 regional ports' profile and characteristics were difficult to obtain because of limited data. However, Digital Logistics Assessment, Marine Traffic database, and World Port Source (WPS) websites helped retrieve data such as the number of terminals, berth length, port area, number of gantries, and draught for major ports within the region but were limited for small ports. The classification of 100 ports in the category of treated (DTrp) and Control (CONTp) ports was classified according to CEPAL and UNCTAD container throughput data. Port ratings were divided into transshipment hubs and ports that improved infrastructural development for mega-ships; therefore, some deep-water ports (mainly Pacific coast) accommodated post-Panamax before PCE were not classified as treatment (DTrp) ports.

Limited research articles were published on DID application within the Maritime field. The main limitation to this technique is the non-verifiability of its assumptions (Schiozer et al. 2020). This model's application to assess causal effects of endogenous and exogenous variables associated with the maritime industry may be proven challenging and may require additional methods to evaluate an intervention's impact. The maritime industry's volatility triggered by exogenous factors such as oil prices, freight rates, natural and economic disasters, wars, etcetera., can create limitations to the DID applications. The parallel trend assumption (PTA), although one of the most popular used methods for determining the DID model's internal validity, as shown in Fig. 7, was the method used to validate the model in this research. However, Kahn-Lang and Lang (2018) believe that the PTA is insufficient to establish the DID's validity. Therefore, other procedures such as the Robustness test and reformulating the model to allow non-parallel pre-period trends can be applied to test the model's validity (Bilinski and Hatfield 2018; Rambachan and Roth 2019).

Economic and environmental variables such as Gross Domestic Product (GDP), Direct Foreign Investment (FDI), maritime pollution, Carbon and Green gas emission from Neo-Panama and Post-Panama vessels were not covered within the scope of this research. Excluding these variables may limit the full justification of the PCE to the region from an economic and environmental perspective.

\section{Conclusion}

This study examined the impact of PCE on 100 ports within the LAC region from 2010 to 2019. The DID model was used to assess the causal effect of the PCE on container 
throughput (TEUs) among ports within the LAC region which includes the three (3) subregions and major transshipment ports. This method was significant for analyzing the Pre and Post PCE era's impact on regional ports since the advent of Neo-Panamax and Post-Panamax vessels (Mega-ships) transiting the PCE in 2016. The DID model's finding revealed that PCE has positively impacted container throughput volumes among LAC regional ports except for the Caribbean regional transshipment ports (DTrp) that experienced TEUs' losses since the PCE (Intervention). The findings were important in evaluating the PCE's causal effect on container throughput volume among LAC ports and determining endogenous factors that may affect regional port competitiveness.

Despite its limitations, the DID model is an alternative approach in impact evaluation that can be used to assess the effectiveness of governmental policies, environmental policies, and socio-economic programs (Hawkins et al. 2015). The DID model can also be used as a guide for policymakers to improve or adjust an intervention's outcome for regional ports. Limited studies were conducted on the DID approach in the maritime sector; therefore, it is recommended that future studies use the DID approach with other variables such as GDP, DFI, and environmental policies (MARPOL Annex VI), to determine the holistic impact of the PCE on the ports within the LAC region.

In general, the maritime sector is volatile and sensitive to the dynamic changes within global trade. Therefore ports that are proactive in assessing the effectiveness of a policy or intervention will have a competitive edge in adjusting or improving endogenous factors (e.g., policies, infrastructure, and trade) to remain sustainable in the maritime industry.

\section{Acknowledgements}

I would like to acknowledge Japanese International Corporation Agency (JICA) for selecting me has a scholarship recipient. I am thankful for this opportunity in my research endeavors.

AVAILABILITY OF DATA AND MATERIAL

- CEPAL (2019). Port Activity report of Latin America and Caribbean. https://www.cepal.org/en/notes/port-activityreport-latin-america-and-caribbean-2018

- United Nations Conference on Trade and Development. (UNCTAD). https://unctad.org/en/Pages/statistics. aspx

- Clarkson Research data 2020https://www.clarksons.net/portal

- Container Port traffic (TEU: 20 Foot equivalent units)https://data.worldbank.org/indicator/IS.SHP.GOOD.TU

- Latin America and Caribbean Ports

http://perfil.cepal.org/l/en/portmovements_classic.html

Authors' contributions

Professor Tetsuro Hyodo is advisor for this research and was instrumental in recommending the appropriate methodology for this article. The author(s) read and approved the final manuscript.

\footnotetext{
Authors' information

Professor Tetsuro Hyodo, head of the department of Logistics and Information engineering. He graduated in Civil Engineering, Tokyo Institute of Technology in 1984. In 1986, completed the master's Course in Civil Engineering at the Graduate School. 1989.Completed the Doctoral Course (Doctor of Engineering). 1998, Visiting Researcher at the Institute of Transportation Research, University of California, Berkeley. He is the author and co-author of several research journals, please see link https://tumsatdb.kaiyodai.ac.jp/html/100000623_ronbn_1_en.html.

Kahuina Hassan Miller, 2nd year Doctoral student from the Tokyo University of Marine Science and Technology (TUMSAT). Course of Applied Marine Environmental Studies specialization logistics and information engineering. He is the graduate World Maritime University (2014), obtaining MSc in Maritime Affair specialization Ship management and Logistics. Email: kahuinam@gmail.com.
}

Funding

All funding for this research is sponsored by the Japan International Corporation Agency (JICA). JICA provides an annual academic budget for research. This budget is managed by Professor Tetsuro Hyodo, Tokyo University of Marine Science and Technology (TUMSAT) from the Department of Logistics and Information engineering. 


\section{Declarations}

\section{Competing interests}

Authors declares no competing interests

Received: 3 September 2020 Accepted: 14 June 2021

Published online: 08 July 2021

\section{References}

Abadie A (2005) Semiparametric difference-in-differences estimators. Review of Economic Studies 72(1):1-19. https:// economics.mit.edu/files/11869. https://doi.org/10.1111/0034-6527.00321

Achurra-Gonzalez P, Novati M, Foulser-Piggott R, Graham D, Bowman G, Bell M, Angeloudis P (2016) Modelling the impact of liner shipping network perturbations on container cargo routing: Southeast Asia to Europe application. Accid Anal Prev 123:399-410. https://doi.org/10.1016/j.aap.2016.04.030

ACS. (2017). The future of the informal shipping sector in the Caribbean | ACS-AEC. ACS-AEC. http://www.acs-aec.org/index. php?q=transport/the-future-of-the-informal-shipping-sector-in-the-caribbean

Albouy D (2004) The Colonial Origins of Comparative Development: A Reinvestigation of the Data. University of California, Berkeley July

Albouy D (2015) Program evaluation and the difference in difference estimator. Economics 131 https://eml.berkeley.edu/ webfac/saez/e131_s04/diff.pdf

Ashley, Z., \& Dettoni, J. (2016). From the depths: canal expansion gives post-Panama papers boost. The Financial Times Ltd. https://www fdiintelligence.com/article/66572

Athey S, Imbens GW (2006) Identification and inference in nonlinear difference-in-differences models. Econometrica 74(2): 431-497. http://www.jstor.org/stable/3598807. https://doi.org/10.1111/j.1468-0262.2006.00668.x

Bertrand M, Duflo E, Mullainathan S (2003) How much should we trust differences-in-differences estimates? Q J Econ 119(1): 249-275 https://economics.mit.edu/files/750

Bhadury J (2016) Panama Canal expansion and its impact on east and Gulf Coast ports of USA. Maritime Policy Manag 43(8): 928-944. https://doi.org/10.1080/03088839.2016.1213439

Bilinski, A., \& Hatfield, L. A. (2018). Seeking evidence of absence: Reconsidering tests of model assumptions. http://arxiv.org/a bs/1805.03273

Card D, Krueger A (1994). Minimum Wages and Employment: A Case Study of the Fast-Food Industry in New Jersey and Pennsylvania. American Economic Association, 84(4):772-793. https://davidcard.berkeley.edu/papers/njmin-aer.pdf.

Carral L, Tarrio-Saavedra J, Castro-Santos L, Lamas-Galdo I, Sabonge RL (2018) Effects of the expanded Panama Canal on vessel size and seaborne transport. PROMET - Traffic Transportation 30(2):241-251. https://doi.org/10.7307/ptt.v30i2.2442

CEPAL (2019). Port activity report of Latin America and the Caribbean 2018 | Briefing note | Economic Commission for Latin America and the Caribbean. Economic Commission for Latin America and the Caribbean. https://www.cepal.org/en/ notes/port-activity-report-latin-america-and-caribbean-2018.

CEPAL (2020). Economic Commission for Latin America and the Caribbean. Ports. http://perfil.cepal.org/l/en/portmovements_ classic.html

Cho, A., Gordon, BL., Bray, WD., Padelford, WE. (2019). Panama Canal. Encyclopedia Britannica. https://www.britannica.com/ topic/Panama-CanalGro

Columbia Public Health. (2020). Difference-in-difference estimation. https://www.publichealth.columbia.edu/research/popula tion-health-methods/difference-difference-estimation

Fan H, Gu W (2019) Study on the impact of the Panama Canal expansion on the distribution of container liner routes. J Transport Technol 9(2):204-214. https://doi.org/10.4236/jtts.2019.92013

Fredriksson A, Oliveira GMD (2019) Impact evaluation using difference-in-differences. RAUSP Manag J 54(4):519-532. https:// doi.org/10.1108/RAUSP-05-2019-0112

FreightWaves (2020). American Shipper-Global trade and shipping news. https://www.freightwaves.com/news/americanshipper

Gooley, T. (2018). Has the Panama Canal expansion changed anything? Transportation report. https://www.dcvelocity.com/a rticles/30335-has-the-panama-canal-expansionchanged-anything

Gro. (2016). Panama Canal expansion: a case of bad timing. Gro Intelligence. https://gro-intelligence.com/insights/articles/pa nama-canal-expansion-a-case-of-bad-timing

Hawkins, A., McDonald, B., Rogers, P., Macfarlan, A., \& Milne, C. (2015). Choosing appropriate designs and methods for impact evaluation. Department of Industry, Innovation and Science. https://www.heritage.org/index/trade-freedom\#:\%7E:text=Tra de\%20freedom\%20is\%20a\%20composite,\%2Dtariff\%20barriers\%20(NTBs)

Heckman JJ, Ichimura H, Todd PE (1997) Matching as an econometric evaluation estimator: evidence from evaluating a job training Programme. Rev Econ Stud 64(4):605-654. https://doi.org/10.2307/2971733

ICS. (2020). Port and Terminal Management (British Ports Association ed., Vol. 268). Institute of Chartered Shipbrokers

Index of Economic Freedom (IEF). (2020). Trade Freedom: Tariffs, Imports, Exports, and Economic Freedom. World Bank. https://www.heritage.org/index/trade-freedom\#:\%7E:text=Trade\%20freedom\%20is\%20a\%20composite,\%2Dtariff\%20ba rriers\%20(NTBs).

Kahn-Lang A, Lang K (2018) The promise and pitfalls of differences-in-differences: Reflections on "16 and Pregnant" and other applications, National Bureau of Economic Research. https://doi.org/10.3386/w24857

Kapoor, R. (2016). Diminishing economies of scale from megaships? Drewry. https:/www.marinemoney.com/system/files/ media/mm/pdf/2016/1150\%20Rahul\%20Kapoor.pdf

Kendrick, R. (2020. The Panama Canal Expansion and the rise of containerized cargo at east coast ports. Xebec Realty. https:// xebecrealty.com/blog/panama-canal-expansion-rise-containerized-cargo-east-coast-ports/

Lechner M (2011) The estimation of causal effects by difference-in-difference methods. Foundations Trends Econ 4(3):165- 
Lim S (2011) Economies of scale in container shipping. Maritime Policy Manag 25(4):361-373. https://doi.org/10.1080/0308883 9800000059

Link, J. (2015). The Panama Canal expansion's massive ripple effect on US ports and shipping. Autodesk.

Liu Q, Wilson WW, Luo M (2016) The impact of Panama Canal expansion on the container-shipping market: A cooperative game theory approach. Maritime Policy Manag 43(2):209-221. https://doi.org/10.1080/03088839.2015.1131863

Lloyd R (2017) The Panama Canal as a determinant of FDI inflows in Panama. Rev Integrative Bus Econ Res 7:87-102

Logistics Capacity Assessments (LCAs) (2021) Brazil: Limited Port Assessment - Logistics Capacity Assessment - Digital Logistics Capacity Assessments. LCA https://dlca.logcluster.org/display/public/DLCA/Brazil+-+Limited+Port+Assessment

Marine Traffic (2021). Global ship tracking intelligence | AIS Marine traffic. Marine Traffic. https://www.marinetraffic.com/en/a is/home/centerx:-15.3/centery:28.0/zoom:2

Marle, G. (2016). Overcapacity may hit Caribbean transhipment ports following Panama Canal expansion. The Loadstar. https://theloadstar.com/overcapacity-may-hit-caribbean-transhipment-ports-following-panama-canal-expansion/

Martinez C, Steven AB, Dresner M (2016) East Coast vs. West Coast: The impact of the Panama Canal's expansion on the routing of Asian imports into the United States. Transport Res Part E 91:274-289. https://doi.org/10.1016/j.tre.2016.04.012

Mckenzie, D. (2021). Revisiting the difference-in-differences parallel trends assumption: Part I Pre-trend testing. World Bank Blogs. https://blogs.worldbank.org/impactevaluations/revisiting-difference-differences-parallel-trends-assumption-part-ipre-trend

Merk O (2018) Container ship size and port relocation, International Transport Forum Discussion Paper, No. 2018-10. Organisation for Economic Co-Operation and Development (OECD), International Transport Forum, Paris. https://doi. org/10.1787/d790ae41-en

Morley H, Ashe A (2019). ARO 2020: US East Coast ports vie for rising cargo volumes. ARO 2020. https:/www.joc.com/portnews/us-ports/aro-2020-us-east-coast-ports-vie-rising-cargo-volumes_20191231.html.

Munim ZH, Schramm HJ (2018). The impacts of port infrastructure and logistics performance on economic growth: the mediating role of seaborne trade. Journal of Shipping and Trade, 3(1). https://doi.org/10.1186/s41072-018-0027-0.

Nicholson G, Boxill K (2017). The Caribbean and the widening of the Panama Canal: panacea or problems? Association of Caribbean States (ACS AEC). http://www.acs-aec.org/index.php?q=fr/node/4325.

Notteboom, T., Pallis, A., \& Rodrigue, J. P. (2021). Port Economics, Management and Policy. Port Economics, Management and Policy | A Comprehensive Analysis of the Port Industry. https://porteconomicsmanagement.org

OECD (2015). Organization for Economic Co-Operation and Development. Competition issues in liner shipping. http://www. oecd.org/officialdocuments/publicdisplaydocumentpdf/?cote=DAF/COMP/WP2(2015)3\&docLanguage $=$ En

OECD (2020). Organization for Economic Co-Operation and Development iLibrary | Foreign direct investment (FDI). https:// www.oecd-ilibrary.org/finance-and-investment/foreign-direct-investment-fdi/indicator-group/english_9a523b18-en

Panama Canal Authority. (2019). Maritime Services - PanCanal.com. Panama Canal Traffic Along Principal Trade Routes. https://www.pancanal.com/eng/op/transit-stats/index.html

Park C, Richardson HW, Park J (2020) Widening the Panama Canal and US ports: Historical and economic impact analyses. Maritime Policy Manag 47(3):419-433. https://doi.org/10.1080/03088839.2020.1721583

Pham T, Kim K, Yeo G (2018) The Panama Canal expansion and its impact on East-West liner shipping route selection. Sustainability 10(12):4353. https://doi.org/10.3390/su10124353

Prozzi J, Overmyer S (2018) The Potential Impacts of the Panama Canal Expansion on Texas Ports. Texas A\&M Trasport Instit PRC 17-78:11-18 https://rosap.ntl.bts.gov/view/dot/34899

Qiu LY, He LY (2017) Can green traffic policies affect air quality? Evidence from a difference-in-difference estimation in China. Sustainability 9(6):1067. https://doi.org/10.3390/su9061067

Rambachan, A., \& Roth, J. (2019). An honest approach to parallel trends [Working paper]. https://scholar.harvard.edu/files/ jroth/files/roth_jmp_honestparalleltrends_main.pdf

Reyes OS, Taneja P, Pielage BA, van Schuylenburg M (2019) Dynamic Planning for Flexible Port Infrastructure after Panama Canal Expansion: A Real Case Study. Ports 2019:3-10 https://doi.org/10.1061/9780784482629.028

Rodrigue, J. P. (2015). How serious are the alternatives to the Panama Canal? | Logistics Regional Observatory. Inter-America Devlopment Bank. http://logisticsportal.iadb.org/node/4212?language=en\#:\%7E:text=At\%20the\%20macro\%20level\%2C\%2 Odue,the\%20Atlantic\%20and\%20Pacific\%20oceans.

Rodrigue, J.P. (2020). Geography of transport systems (5th ed). The Geography of Transport Systems. https:// transportgeography.org/geography-of-transport-systems-5th-edition/

Rodrigue JP, Ashar A (2016) Transshipment hubs in the New Panamax Era: The role of the Caribbean. J Transport Geography 51 (C):270-279 https://www.researchgate.net/publication/284017736_Transshipment_hubs_in_the_New_Panamax_Era_ The_role_of_the_Caribbean

Sarriera, J., Suárez-Alemán, A., Serebrisky, T., \& Trujillo, L. (2015). When it comes to container port efficiency, are all developing regions equal? (IDB Working Paper Series no. IDB-WP-568). https:/publications.iadb.org/publications/english/document/ When-It-Comes-to-Container-Port-Efficiency-Are-All-Developing-Regions-Equal.pdf

Schiozer R, Mourad AF, Martins CT (2020) A Tutorial on the Use of Differences-in-Differences in Management, Finance, and Accounting. Rac: Revista De Administração Contemporânea 25:1

Shibasaki R, Usami T, Furuichi M, Teranishi H, Kato H (2018) How do the new shipping routes affect Asian liquefied natural gas markets and economy? Case of the Northern Sea Route and Panama Canal expansion. Maritime Policy Manag 45(4): 543-566. https://doi.org/10.1080/03088839.2018.1445309

Singh, A., Asmath, H., Leung Chee, C., \& Darsan, J. (2015). Marine Pollution Bulletin. Potential Oil Spill Risk from Shipping and the Implications for Management in the Caribbean Sea 93(1-2), 217-277. doi: https://doi.org/10.1016/j.marpolbul.2015.01. 013.

Talley WK (2006) Chapter 22 Port performance: An economics perspective. Res Transport Econ 17:499-516. https://doi.org/1 $0.1016 / 50739-8859(06) 17022-5$

Thomas, A. R. (2015). Suez and Panama: A Healthy Competition. IndustryWeek. https://www.industryweek.com/ideaxchange/a rticle/21965825/suez-and-panama-a-healthy-competition

UNCTAD (2014). Review Of Maritime Transport: 2013. United Nations. https://unctad.org/system/files/official-document/rmt2 013_en.pdf. 
UNCTAD. (2021). Port liner shipping connectivity index, quarterly. UNCTAD STAT. https://unctadstat.unctad.org/wds/ ?aspxerrorpath=/wds/TableViewer/tableView.aspx

United Nations (2005) World Investment Report. United Nations publication https:/unctad.org/system/files/officialdocument/wir2005_en.pdf.

Van Hassel, E., Meersman, H., Voorde, E., \& Vanelslander, T. (2020). The impact of the expanded Panama Canal on port range choice for cargo flows from the U.S. to Europe. Maritime Policy Manag. 1-19. doi: https://doi.org/10.1080/03088839.202 0.1718230 .

Wang M (2017) The role of Panama Canal in global shipping. Maritime Bus Rev 2(3):247-260. https://doi.org/10.1108/MABR07-2017-0014

White H, Sabarural S (2014) Quasi-Experimental Design and Methods. Methodological briefs, impact evaluation No. 8. UNICEF, September 2014

Wilmsmeier G, Hoffmann J, Sanchez RJ (2006) The impact of port characteristics on international maritime transport costs. Res Transport Econ 16:117-140. https://doi.org/10.1016/S0739-8859(06)16006-0

Wing C, Simon K, Bello-Gomez RA (2018) Designing difference in difference studies: Best practices for public health policy research. Ann Rev Public Health 39(1):453-469. https://doi.org/10.1146/annurev-publhealth-040617-013507

World Bank (2021). Container port traffic (TEU: $20 \mathrm{ft}$ equivalent units) | data. WorldBank. https://data.worldbank.org/indicator/ IS.SHP.GOOD.TU

World Economic Forum (2018). The global competitiveness index 4.0 methodology and technical notes. The Global Competitiveness Report. http://www3.weforum.org/docs/GCR2018/04Backmatter/3.\%20Appendix\%20C.pdf

World Port Source. (2021). WPS - Home Page. http://www.worldportsource.com/

World Shipping Council (WSC) (2019). Trade routes. World Shipping Council. https://www.worldshipping.org/about-theindustry/global-trade/trade-routes

Zupanovic D, Grbić L, Barić M (2019) The impact of the new Panama Canal on cost-savings in the shipping industry. TransNav Int J Marine Navigation Safety SEA Transport 13(3):537-541. https://doi.org/10.12716/1001.13.03.07

\section{Publisher's Note}

Springer Nature remains neutral with regard to jurisdictional claims in published maps and institutional affiliations.

\section{Submit your manuscript to a SpringerOpen ${ }^{\circ}$ journal and benefit from:}

- Convenient online submission

$\checkmark$ Rigorous peer review

- Open access: articles freely available online

High visibility within the field

- Retaining the copyright to your article

Submit your next manuscript at $\boldsymbol{\nabla}$ springeropen.com 